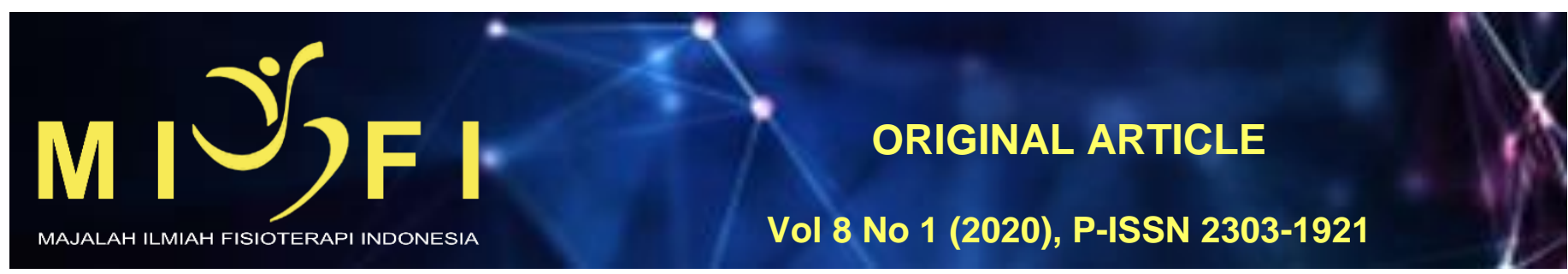

\title{
KECEPATAN LARI PADA PEMAIN BASKET PUTRI DENGAN GENU VALGUM NORMAL DAN ABNORMAL DI SMA NEGERI KOTA DENPASAR
}

\author{
Kadek Rista Harjayanti ${ }^{1}$, Ni Komang Ayu Juni Antari ${ }^{2}$, Putu Ayu Sita Saraswati ${ }^{3}$, I Nyoman Adiputra \\ ${ }^{1}$ Program Studi Sarjana Fisioterapi dan Profesi Fisioterapi, Fakultas Kedokteran Universitas Udayana \\ 2,3Departemen Fisioterapi, Fakultas Kedokteran Universitas Udayana \\ ${ }^{4}$ Departemen Fisiologi, Fakultas Kedokteran Universitas Udayana
}

kadekrista8@gmail.com

\begin{abstract}
ABSTRAK
Kecepatan lari dalam olahraga basket sangat dibutuhkan, karena pemain harus memiliki kecepatan dribbling atau menggiring bola yang cepat serta dapat membelokkan arah bola dengan cepat. Permasalahan dalam struktur dan fungsi tubuh seperti genu valgum akan memberikan pengaruh pada kecepatan lari pada atlet yang dapat mempengaruhi performa dan prestari atlet. Penelitian ini bertujuan untuk mengetahui perbedaan kecepatan lari pada pemain basket putri dengan genu valgum normal dan abnormal. Desain penelitian ini yaitu analitik dengan pendekatan potong lintang. Jumlah sampel sebanyak 46 pemain basket putri berusia 16 - 19 tahun. Variabel bebas yang diukur adalah genu valgum normal dan abnormal sedangkan variabel terikatnya yaitu kecepatan lari. Hasil penelitian menunjukkan nilai $p$ $=0,000(p<0,05)$ dengan nilai rerata kecepatan lari pada kelompok genu valgum normal dan abnormal masing masing $10,83 \pm 0,61$ detik dan 12,13 $\pm 1,02$ detik. Kesimpulan dari penelitian ini yaitu terdapat perbedaan kecepatan lari yang signifikan pada pemain basket putri dengan genu valgum normal dan abnormal, dimana kecepatan lari pada kelompok genu valgum abnormal lebih rendah sebesar $11,32 \%$ dibandingkan dengan kelompok genu valgum normal.

Kata Kunci: genu valgum, kecepatan lari, $q$-angle, pemain basket
\end{abstract}

\section{RUNNING SPEED IN FEMALE BASKET PLAYERS WITH NORMAL AND ABNORMAL VALGUM GENU IN DENPASAR CITY STATE HIGH SCHOOL}

\section{ABSTRACT}

Running speed in basketball is needed, because players must have the speed of dribbling or dribbling fast and can turn the direction of the ball quickly. Problems in the structure and function of the body such as the valgum genu will have an effect on the running speed in athletes which can affect the performance and performance of athletes. This study aims to determine the difference in running speed in women's basketball players with normal and abnormal valgum genu. The design of this research is analytic with cross sectional approach. The number of samples is 46 female basketball players aged 16-19 years. The independent variable measured is normal and abnormal valgum genu while the dependent variable is running speed. The results showed a value of $p=0,000(p<0.05)$ with a mean running speed in the normal and abnormal valgum genu group of $10.83 \pm 0.61$ seconds and $12.13 \pm 1.02$ seconds, respectively. The conclusion of this study is that there is a significant difference in running speed in female basketball players with normal and abnormal valgum genu, where the running speed in the abnormal valgum genu group is $11.32 \%$ lower than the normal valgum genu group.

Keywords: genu valgum, running speed, q-angle, basketball player 


\section{PENDAHULUAN}

Lutut merupakan salah satu bagian tubuh yang berfungsi untuk menopang tubuh seseorang. Apabila lutut tidak berfungsi dengan baik maka dapat mengganggu aktivitas fisik seperti berjalan, berlari dan sebagainya. Salah satu masalah yang tejadi pada lutut adalah deformitas sendi seperti genu valgum. Genu valgum atau disebut juga dengan knock knee merupakan kondisi kaki membentuk huruf $\mathrm{X}$, dimana lutut meyimpang menuju garis tengah tubuh dan bersentuhan satu sama lain ketika kaki diluruskan. Genu valgum maksimum umumnya terlihat pada anak usia 3-4 tahun. Dan dengan sendirinya membentuk sudut tibiofemoral dewasa normal sebelum usia 8 tahun. ${ }^{1}$

Wanita umumnya memiliki sudut $Q$ yang lebih besar. ${ }^{2}$ Secara anatomis wanita memiliki panggul yang lebih lebar dibandingkan pria. Pelvis yang lebar memungkinkan peningkatan genu valgum karena angulasi femur di bidang frontal harus lebih besar untuk mempertahankan stance width. Pelvis yang lebih lebar akan memindahkan pusat massa tubuh lebih ke medial hip joint sehingga gravitasi akan menciptakan peningkatan adduksi selama berdiri. ${ }^{3}$

Banyak faktor resiko yang menyebabkan terjadinya genu valgum abnormal diantaranya usia, jenis kelamin, indeks massa tubuh, flat foot, trauma dan aktivitas fisik. Salah satu faktor risiko terjadinya genu valgum adalah trauma yang berkaitan dengan cedera ekstremitas bawah pada atlet yang melibatkan gerakan-gerakan zig-zag, perubahan arah, gerak, dan kecepatan yang mendadak seperti pada olahraga basket. Aktivitas fisik seperti latihan fisik pada altlet yang dapat mengembangkan deviasi postur. ${ }^{4}$

Deviasi postur yang cukup besar dapat mempengaruhi efisiensi otot dan menyebabkan masalah pada muskuloskeletal dan saraf. Jika segmen tubuh dijauhkan dari alignment tubuh untuk waktu yang lama, otot akan beristirahat dalam posisi memanjang atau memendek dan seiring waktu dapat terjadi pemanjangan dan pemendekan adaptif. Pemendekan otot adaptif dapat dideskripsikan sebagai otot yang tight dan menyebabkan otot berlawanan dalam keadaan memanjang atau weakness. Perubahan panjang otot ini dapat mempengaruhi posture alignment. ${ }^{5}$

Atlet dengan kelainan bentuk lutut genu valgum akan mengalami misalignment tulang patela, ketidaknyamanan lutut, ketidak stabilan ligamen, dan gangguan fungsional lainnya seperti pola jalan yang berubah, ketidakstabilan postur tubuh, dan kesulitan dalam berdiri, berjalan, dan berlari. Permasalahan dalam struktur dan fungsi tubuh menyebabkan permasalahan dalam sistem fungsionalnya akan memberikan pengaruh pada kecepatan lari atlet. ${ }^{6}$

Kecepatan lari dipengaruhi oleh fakor internal dan faktor eksternal. Faktor internal meliputi genetik, umur, jenis kelamin, indeks massa tubuh, panjang tungkai, dan kelainan bentuk lutut, sedangkan faktor eksternal meliputi suhu, kelembaban, arah dan kecepatan angin, serta ketinggian tempat. ${ }^{7}$

Melihat pentingnya kecepatan lari bagi atlet dan belum adanya penelitian mengenai hal ini di Indonesia, peneliti tertarik untuk melakukan penelitian mengenai "Kecepatan Lari pada Pemain Basket Putri dengan Genu valgum Normal dan Abnormal di SMA Negeri Kota Denpasar". Hal ini penting dilakukan sebagai upaya dalam meningkatkan prestasi altet khususnya di Indonesia.

\section{METODE}

Desain penelitian ini menggunakan rancangan analitik dengan pendekatan potong lintang. Penelitian ini dilakukan di seluruh Sekolah Menegah Atas Negeri (SMAN) kota Denpasar. Penelitian dilakukan pada bulan April 2019. Jumlah sampel pada penelitian ini yaitu 46 pemain basket. Sampel dipilih menggunakan teknik purposive sampling dan memenuhi kriteria inklusi dan eksklusi diantaranya pemain basket putri usia 16-19 tahun, anggota aktif ekstrakulikuler basket minimal 6 bulan, Indeks Massa Tubuh (IMT) normal, tidak menderita genu varum, tidak menderita gangguan kardiorespirasi, tidak sedang dalam perawatan setelah operasi atau mengalami cedera akut pada lutut, dan tidak sedang dalam penggunaan Knee Ankle Foot Orthosis (KAFO).

Variabel independent yang diukur adalah genu valgum normal dan abnormal, sedangkan variabel dependen yang diukur adalah kecepatan lari. Pengukuran Q-Angle menggunakan goniometer digunakan untuk mengetahui adanya genu valgum normal dan abnormal. Dinyatakan genu valgum normal apabila membentuk $Q$-angle diantara 1517 derajat sedangkan genu valgum abnormal jika membentuk Q-angle lebih dari 17 derajat. Kecepatan lari diukur dengan mencatat waktu tempuh dalam tes lari sprint 60 meter dengan satuan detik.

Setelah data terkumpul, kenormalan persebarannya diuji dengan menggunakan uji Shapiro Wilk. Uji Hipotesis dilakukan dengan menggunakan uji Mann-Whitney untuk membandingkan skor dua kelompok independen dan sebagai pengganti Independent T-test.

\section{HASIL}

Karakteristik sampel berdasarkan usia, IMT, kategori genu valgum normal dan abnormal serta nilai kecepatan lari ialah sebagai berikut.

Tabel 1. Distribusi Karakteristik Sampel Berdasarkan Usia dan Kelompok Genu Valgum Normal dan Abnormal

\begin{tabular}{lcc} 
Karakteristik & $\begin{array}{c}\text { Frekuensi } \\
\text { (n) }\end{array}$ & $\begin{array}{c}\text { Persentase } \\
(\%)\end{array}$ \\
\hline Usia & & \\
16 tahun & 20 & 43,5 \\
17 tahun & 20 & 43,5 \\
18 tahun & 6 & 13 \\
19 tahun & 0 & 0 \\
Genu Valgum & & \\
Normal & 23 & 50 \\
Abnormal & 23 & 50 \\
\hline
\end{tabular}


Tabel 1. menunjukkan sampel paling banyak dalam penelitian ini ialah pemain usia 16 dan 17 tahun yang berjumlah 20 orang (43,5\%) dengan jumlah sampel terkecil ialah usia 18 tahun berjumlah 6 orang (13\%) dan tidak ditemukan sampel berusia 19 tahun. Karakteristik sampel berdasarkan genu valgum normal dan abnormal memiliki jumlah sama banyak yaitu berjumlah 23 siswa dengan persentase masing-masing 50\%.

Tabel 2. Distribusi Karakteristik Sampel Berdasarkan IMT

\begin{tabular}{ccc}
\hline Karakteristik & Rerata & Simpang Baku \\
\hline IMT $\left(\mathrm{kg} / \mathrm{m}^{2}\right)$ & 21,28 & 1,74 \\
\hline
\end{tabular}

Tabel 2. memperlihatkan bahwa rerata indeks massa tubuh pada sampel yang berjumlah 46 siswa yaitu sebesar $21,276 \mathrm{~kg} / \mathrm{m}^{2}$.

Tabel 3. Hasil Uji Normalitas Kecepatan Lari (Waktu Tempuh) pada Kelompok Genu valgum Normal dan Abnormal

\begin{tabular}{cccc}
\hline Kelompok & $\begin{array}{c}\text { Rerata } \pm \text { SB } \\
\text { (detik) }\end{array}$ & p \\
${$\cline { 1 - 2 }$} }$ & $10,83 \pm 0,61$ & 0,043 \\
Genu valgum Abnormal & $12,13 \pm 1,02$ & 0,428 \\
\hline
\end{tabular}

Tabel 3. memperlihatkan hasil uji normalitas menggunakan Shapiro Wilk. Berdasarkan hasil di atas, maka dapat dinyatakan bahwa persebaran data tidak normal karena tidak semua variabel memiliki nilai $p>0,05$. Analisis data menggunakan uji non parametrik yaitu uji Mann-Whitney. Hasil uji terdapat pada Tabel 4. Di bawah ini.

Tabel 4. Hasil Uji Hipotesis Kecepatan Lari (Waktu Tempuh) pada Kelompok Genu valgum Normal dan Abnormal

\begin{tabular}{|c|c|c|c|}
\hline Variabel & $\begin{array}{c}\text { Kelompok } \\
\text { Genu valgum Normal } \\
\text { Rerata } \pm \text { SB } \\
\text { (detik) }\end{array}$ & $\begin{array}{c}\text { Kelompok } \\
\text { Genu valgum Abnormal } \\
\begin{array}{c}\text { Rerata } \pm \text { SB } \\
\text { (detik) }\end{array} \\
\end{array}$ & $\mathbf{p}$ \\
\hline Kecepatan Lari (Waktu Tempuh) & $10,83 \pm 0,61$ & $12,13 \pm 1,02$ & 0,000 \\
\hline
\end{tabular}

Berdasarkan analisis yang dilakukan dengan menggunakan uji Man-Whitney didapatkan nilai $p=0,000$ ( $p<$ $0,05)$. Hal ini menunjukkan adanya perbedaan kecepatan lari yang bermakna pada kelompok genu valgum normal dan abnormal. Tabel 4. menunjukkan nilai rerata kecepatan lari (waktu tempuh) pada kelompok genu valgum normal ialah 10,83 detik dan kelompok genu valgum abnormal memiliki nilai rerata 12,13 detik. Dari tabel tersebut dapat diketahui adanya perbedaan kecepatan lari (waktu tempuh) pada kelompok genu valgum abnormal dengan selisih 1,3 detik atau sebesar $11,32 \%$ dibandingkan dengan kelompok genu valgum normal.

\section{DISKUSI \\ Karakteristik Sampel Penelitian}

Karakteristik sampel pada penelitian didapat dari hasil analisis data yang telah dilakukan terhadap karakteristik usia dan IMT. Sampel dalam penelitian ini merupakan pemain basket putri dengan usia 16-19 tahun. Secara fisiologis, genu valgum muncul dari usia 2 tahun dan mencapai level maksimum pada usia 3-4 tahun, dan dengan sendirinya membentuk sudut tibiofemoral dewasa normal sebelum usia 8 tahun. Wanita usia 16-19 tahun telah mengalami perubahan bentuk tubuh yang secara anatomis memiliki panggul yang lebih lebar dibandingkan pria yang memungkinkan terjadinya peningkatan genu valgum. Hal tersebut didukung oleh penelitian yang dilakukan oleh Souza et al (2013), dimana prevalensi genu valgum perempuan ditemukan sebesar $59,2 \%$ dibandingkan laki-laki $53,6 \%{ }^{8}$ Menurut Utomo (2018), pada usia 15-19 tahun terjadi pembentukan tulang yang pesat yang merupakan massa persiapan untuk mencapai pada puncak masa pertumbuhan tulang (peak bone mass). Pertumbuhan tulang yang normal akan menghasilkan kinerja kecepatan yang optimal. Kelainan bentuk pada tulang akan berpengaruh pada kecepatan lari seseorang, pertumbuhan tulang yang abnormal akan menghasilkan kinerja kecepatan yang tidak optimal. ${ }^{9}$

\section{Kecepatan Lari pada Kelompok Genu valgum Normal dan Abnormal}

Kecepatan lari pada masing-masing kelompok diketahui berdasarkan nilai rerata waktu tempuh dengan berlari sejauh 60 meter pada pemain basket putri. Pada kelompok genu valgum normal didapatkan rerata 10,83 detik dengan standar deviasi 0,61, sedangkan nilai rerata kecepatan lari (waktu tempuh) pada kelompok genu valgum abnormal didapatkan 12,13 detik dengan standar deviasi 1,02. Hasil uji hipotesis dengan Mann-Whitney memperlihatkan nilai yang diperoleh $p=0,000(p<0,05)$ sehingga dapat disimpulkan bahwa terdapat perbedaan kecepatan lari yang bermakna pada kelompok genu valgum normal dan abnormal. Penelitian ini menunjukkan bahwa kecepatan lari (waktu tempuh) pada kelompok genu valgum abnormal lebih lambat dengan selisih 1,3 detik atau sebesar $11,32 \%$ dibandingkan dengan kelompok genu valgum normal.

Hal tersebut didukung oleh penelitian yang dilakukan oleh Souza et al (2013), menganalisis 274 siswa berusia 7 sampai 18 tahun menunjukkan hubungan yang signifikan antara derajat genu valgum dan variabel kebugaran fisik meliputi massa tubuh, kelincahan dan kecepatan berlari seseorang. Ditemukan prevalensi genu valgum sebesar $68,6 \%$ dan mengamati bahwa remaja yang memiliki derajat valgum yang lebih besar mengalami penurunan sekitar $10 \%$ dalam tes kecepatan. ${ }^{8}$

Penelitian sebelumnya yang dilakukan di Iran oleh Fariba et al (2012), dengan menggunakan sampel 137 wanita usia 12 sampai 17 tahun dengan genu valgum abnormal juga mengungkapkan bahwa peningkatan keparahan genu valgum menurunkan kinerja kecepatan. Penelitian yang sama juga disebutkan bahwa pemendekan dan 
kelemahan otot ekstremitas bawah pada individu dengan genu valgum abnormal merupakan faktor yang paling penting dalam menurunkan kinerja kecepatan. ${ }^{10}$

Genu valgum disebut juga dengan knock knee merupakan deformitas pada sendi lutut, dimana axial alignment pada ekstremitas bawah terganggu sehingga membentuk sudut tibiofemoral yang berlebihan. ${ }^{10}$ Orang-orang dengan genu valgum akan mengalami misalignment tulang patela, ketidaknyamanan lutut, ketidakstabilan ligamen, dan gangguan fungsional lainnya seperti pola jalan yang berubah, ketidakstabilan postur tubuh, dan kesulitan dalam berdiri, berjalan, berlari, dan naik turun tangga. ${ }^{7}$

Posisi dan fungsional sendi akan mempengaruhi kinerja dan fungsi otot seseorang saat berlari. Orang dengan posisi dan fungsional sendi yang normal, akan menghasilkan kinerja fungsi otot yang optimal. Berbeda dengan orang yang memiliki permasalahan pada sistem fungsional seperti adanya permasalahan pada sendi lutut yang menyebabkan seseorang memiliki genu valgum. Hal tersebut dapat menimbulkan permasalahan pada stabilitas sendi dinamis seseorang. ${ }^{7}$

Stabilitas pada setiap sendi terutama sendi pada tungkai dan kaki sangat diperlukan pada saat berlari. Stabilitas sendi yang baik akan mempengaruhi sendi, otot dan tulang bekerja sesuai dengan fungsinya sehingga menghasilkan performa lari yang optimal. ${ }^{7}$ Ketika sendi tidak stabil, cenderung terjadi disfungsi pola gerak yang menimbulkan reaksi spontan oleh tubuh untuk memperbaikinya. Pada gangguan stabilitas sendi, akan timbul gerakan kompensasi pada otot-otot disekitar sehingga menimbulkan ketidakstabilan pada fungsi otot. Akibatnya, performa lari akan menurun. ${ }^{12}$

Saat lari terdapat tiga fase utama untuk berlari yaitu fase stance, fase float dan fase swing. Pada fase berlari, durasi saat kaki tidak menyentuh tanah yaitu fase swing dan fase float lebih lama dibandingkan dengan fase stance. Fase swing dan fase float pada siklus lari terjadi sekitar $60 \%$ dan $40 \%$ dihabiskan dengan kaki menyentuh tanah yaitu pada fase stance. Fase stance diawali dengan initial foot strike dan diakhiri dengan toe-off. Fase Swing diawali oleh fase toe-off dan diakhiri oleh foot strike pada sisi ipsilateral yang kedua kalinya. ${ }^{13}$

Hampir semua otot pada tungkai dan kaki berfungsi saat berlari. Otot gastrocnemius dan otot soleus berperan saat gerakan kaki ekstensi atau disebut plantar fleksi sehingga kaki akan menekan tanah. Untuk melangkah selanjutnya, otot tibialis anterior akan berperan untuk menggerakkan kaki dorso fleksi sehingga kaki kembali menginjak tanah dengan tumit. ${ }^{14}$ Otot quadricep terdiri dari otot vastus medialis, vastus intermedius, rectus femoris dan vastus lateralis terletak di paha bagian depan. Saat berlari otot quadricep berperan untuk gerakan ekstensi lutut yaitu ketika tungka tungkai bawah bergerak dari posisi menekuk ke posisi lurus. Otot hamstring terdiri dari otot biceps femoris, semitendinosus and semimembranosus terletak di paha bagian belakang. Otot hamstring akan berperan saat kaki terangkat dari tanah dan tungkai memulai gerakan maju selama berlari. ${ }^{7}$

Otot hamstring dan otot gluteus maximus akan berkontraksi saat gerakan ekstensi hip yaitu ketika mulai gerakan melangkahkan tungkai. Otot addukor dan otot abduktor terletak di dalam dan di luar paha berfungsi sebagai stabilitas pinggul dan mencegah lutut jatuh ke arah dalam atau keluar. Otot ini bekerja secara isometrik dan menghasilkan kekuatan namun tidak benar-benar bergerak. ${ }^{7}$

Genu valgum abnormal menyebabkan peningkatkan pada $Q$-angle. Q-angle sangat dipengaruhi oleh vektor musculus quadriceps femoris, dimana semakin kuat musculus quadriceps femoris akan semakin besar nilai $Q$-angle. Musculus quadriceps femoris merupakan otot yang berperan dalam gerakan esktensi pada pergerakan articulation genus. Q-angle berkorelasi positif dengan durasi untuk mencapai rotasi internal maksimal articulatio genus pada fase swing. Maka, dapat diasumsikan bahwa besar Q-angle berkorelasi positif dengan durasi mencapai ekstensi optimal articulatio genus. Sudut articulatio genus pada saat toe-off berkorelasi positif dengan rata-rata kecepatan melangkah. Adanya korelasi positif yang nilainya besar untuk sudut articulatio genus pada saat toe-off dengan kecepatan lari menunjukkan bahwa ekstensi yang optimal pada sendi-sendi tersebut sangat penting pada fase akselerasi. ${ }^{12}$

Genu valgum cenderung mengakibatkan rotasi pada medial paha, sehingga mempengaruhi kondisi lengkung arkus yang rendah atau overpronasi. Pronasi yang berlebihan akan mempengaruhi fase push off yang terjadi dalam biomekanik berjalan dan berlari. ${ }^{15}$ Saat fase push off, pronasi yang berlebihan mengakibatkan ketidakstabilan struktur pedis, sedangkan seharusnya pada fase ini dibutuhkan stabilisasi yang baik sehingga terjadi dorongan kedepan pada tungkai untuk meningkatkan kecepatan lari. Pronasi yang berlebihan pada forefoot juga akan mengakibatkan peningkatan ground reaction force pada bagian medial tibia. Hal ini akan mengakibatkan otot bekerja lebih keras sehingga akan menyebabkan kelelahan otot dan mempengaruhi kemampuan berlari. ${ }^{16}$

Penelitian ini dapat memberikan edukasi terkait kondisi genu valgum abnormal serta dampaknya terhadap kecepatan berlari khususnya pada pemain basket. Kecepatan lari dalam olahraga basket sangat dibutuhkan karena kecepatan merupakan kemampuan untuk menempuh jarak tertentu terutama jarak pendek, dalam waktu yang sesingkat-singkatnya. Pemain harus memiliki kecepatan dribbling atau menggiring bola yang cepat serta dapat membelokkan arah bola dengan cepat. ${ }^{17}$ Melihat pentingnya kecepatan lari bagi atlet, maka perlu ditingkatkannya kesadaran untuk mencegah dan menangani permasalahan dalam struktur dan fungsi tubuh seperti genu valgum abnormal yang akan memberikan pengaruh pada performa seorang atlet. Latihan penguatan quadriceps mampu memperbaiki Q-angle. ${ }^{18}$

Hasil penelitian yang telah dilakukan oleh Adhitya et al (2017) membuktikan bahwa Closed Kinetic Chain (CKC) Exercise dan stretching dapat menurunkan Q-angle berlebih pada wanita secara signifikan dengan latihan 2 kali seminggu selama 8 minggu. Hasil penelitian ini turut membuktikan bahwa latihan Closed Kinetic Chain juga sangat diperlukan sebagai terapi pada atlet yang memiliki $Q$-angle berlebih karena latihan CKC mampu meningkatkan fungsi otot, menurunkan tingkat kelelahan otot quadriceps dan menyeimbangkan fungsi otot Vastus Medial Oblique (VMO) dengan Vastus Lateral (VL). Pemasangan Kinesiology Tape pada saat melakukan latihan CKC akan membantu menstabilkan sendi sehingga pada saat latihan squats dan lunges lutut tidak terdorong ke dalam atau membentuk sudut 
yang malah akan merusak stabilitas lutut bagian dalam sehingga akan mendapatkan hasil yang lebih maksimal untuk menurunkan Q-angle. ${ }^{18}$

Bagi peneliti yang ingin melanjutkan penelitian ini dapat menambahkan pengukuran yang lebih spesifik dan akurat seperti radiografi atau mengkombinasikan pengukuran $Q$-angle ini dengan alat ukur lainnya. Faktor-faktor yang dapat mempengaruhi kecepatan lari seperti genetik, panjang tungkai, dan aktivitas fisik yang tidak dapat dikontrol dalam penelitian ini agar lebih diperhatikan lagi. Apabila memungkinkan dapat dilakukan pula penelitian terkait hubungan genu valgum abnormal dengan kemampuan motorik lainnya selain kecepatan lari atau dapat dijadikan eksperimen berupa terapi latihan atau intervensi modalitas yang efektif terhadap genu valgum abnormal.

\section{SIMPULAN}

Berdasarkan hasil penelitian yang telah dilakukan maka dapat disimpulkan bahwa terdapat perbedaan kecepatan lari yang signifikan pada pemain basket putri dengan genu valgum normal dan abnormal, dimana kecepatan lari pada kelompok genu valgum abnormal lebih rendah sebesar 11,32\% dibandingkan dengan kelompok genu valgum normal.

\section{DAFTAR PUSTAKA}

1. Das SP, Pradhan S, Sahoo, PK, Mohanty, RN \& Das, SK. Our Experience With Correction of Angular Deformities of Knee by Flexible Figure Of 8-Plate Hemiepiphysiodesis. IJPMR. 2012;23(2):68-73

2. Madani, A, Parsaii SA, Yeganeh, A \& Shahoseini, G. The correlation between Q-angle (clinical) and TTTG distance (axial computed thomography) in Firuzgar Hospital, 2008. Journal of the Islamic Republic of Iran. 2010;23(4):189199.

3. Daneshmandi, H, Saki, F \& Shahheidari, S. Lower extremity malalignment andlinear relation with $Q$ Angle in Female Athletes; 2010

4. Zein, MI. Cedera Anterior Cruciate Ligament (ACL) pada Atlet Berusia Muda. Medikora. 2013;11(2):111-121

5. Esmaeili, AM, Daneshmandi, H \& Samami, N. The Study of Relationship Malalignment Knee and Foot with Injury in Professional Sprinters. International Journal of Sport Studies. 2015;5(5):576-581

6. Ganesan, B, Fong, KNK, Luximon A, \& Al-Jumaily. Kinetic and Kinematic Analysis of Gait Pattern of 13 Year Old Children with Unilateral Genu valgum. European Review for Medical and Pharmalogical Science. 2016;3168-3171

7. Kardha, DS. Kombinasi Pelatihan Core Stability dan Pelatihan Lari Konvensional Lebih Efektif Meningkatkan Kecepatan Lari daripada Pelatihan Lari Konvensional pada Siswa Ekstrakurikuler Sepak Bola. [Internet]. 2016. Available at: https://sinta.unud.ac.id/uploads/dokumen dir/687ab2d7ad21ab136b942b58d91a2e57.pdf . [Accessed 14 January 2019]

8. Souza, AA, Gerson Luis de MF, João Pedro da SJ, Leonardo José da S, Luis Carlos de O \& Victor Keihan RM. Association Between Knee Alignment, Body Mass Index and Physical Fitness Variables Among Students: A CrossSectional Study. Rev Bras Ortop. 2013;48(1):46-51.

9. Utomo, SPP. Hubungan Indeks Massa Tubuh dan Core Stability dengan Kecepatan Lari. Surakarta: Universitas Muhammadiyah Surakarta; 2018

10. Fariba, GT, Aghayari. Azar, A. Mohammadreza. Relationship Between Genu valgum Abnormality and Record of 45-M Sprint in Girls Student Amonge 12-17 Years Old of Germi City. International shomal Sport Science Conference; 2012

11. Farr, S., Kranzl, A., Pablik, E, Kaipel, M \& Ganger, R. Functional and Radiographic Consideration of Lower Limb Malalignment in Children and Adolescents With Idiopathic Genu valgum; 2014

12. Pradaningpuri, DD. Hubungan Faktor-Faktor Kinesiologi dengan Kecepatan Lari 100 Meter Mahasiswa FK UNDIP. Semarang: Universitas Diponegoro; 2018

13. Panariello, R. Should the Rehabilitation and Strength \& Conditioning Professional Abandon "Traditional" Bilateral Leg Exercise for Single-Leg Exercise Performance? Available from: http://www.strengthpowerspeed.com/single_or_double/ . [Accessed 14 January 2019]

14. Dale, P. What Muscles Does Running Build?. 2015. Available at : http://www.livestrong.com/article/111142musclesrunning-build/. [Accessed 15 January 2019]

15. Milner, CE. Functional Anatomy for Sport and Exercise. New York: Madison Ave; 2008

16. Dugan SA \& Bhat KP. Biomechanics and Analysis of Running Gait. Phys Med Rehabil Clin N Am. 2005;16(3):60321.

17. Supian, A. Kontribusi Kecepatan Lari dan Kelincahan terhadap Kecepatan Dribbling Bola Basket pada Pemain Basket Putra SMKN 3 Banjarbaru. Jurnal Multilateral. 2014;13(1):37-52

18. Adhitya, S, Adiputra, IN, Lesmana, SI, Sutjana, DP, Muliarta, IM. Imron, MA. Penambahan Kinesiology Tape pada Pelatihan Closed Kinetic Chain (CKC) dan Stretching Lebih Baik dalam Menurunkan Excessive Q-Angle pada Wanita. Sport and Fitness Journal. 2017;5(3):93-100 